\title{
PENGARUH IKLIM ORGANISASI DAN KOMITMEN ORGANISASI TERHADAP ORGANIZATIONAL CITIZENSHIP BEHAVIOR (OCB)
}

\author{
Imran Ukkas ${ }^{1}$, Dirham Latif ${ }^{2}$ \\ Sekolah Tinggi Ilmu Ekonomi Muhammadiyah Palopo \\ ${ }^{1}$ E_Mail: imranukkas@stiem.ac.id
}

\begin{abstract}
In certain conditions, employees are not always be able to do the job descriptions that have been assigned by the company caused by several things, for example, employees have some obstructions caused by certain reasons. At this point, the role of $O C B$ is very indispensable in a team work. This research aims to determine the effect of organizational climate and organizational commitment on Organizational Citizenship Behavior (OCB) to the employees of PT. PLN (Persero) Area Palopo. The research took sample 113 employees. The analysis used in this research is descriptive quantitative analysis method called equational of multiple linear regression. The result of this research showed a significant positive effect between organizational climate and organizational commitment on Organizational Citizenship Behavior (OCB) to the employees either partially or simultaneously. So this research could be a reference for PT. PLN (Persero) Area Palopo to keep improving the quality of employee's performance through Organizational Citizenship Behavior (OCB).
\end{abstract}

Keywords: Organizational Climate, Organizational Commitment, Organizational Citizenship Behavior(OCB)

\section{PENDAHULUAN}

Berhasil atau tidaknya sebuah perusahaan biasanya akan ditandai oleh kemampuan perusahaan tersebut dalam mengelola sumber daya manusia yang dimiliki. Sumber daya manusia yang dibutuhkan dalam sebuah perusahaan tentunya harus mempunyai kualitas kerja yang tinggi. Hal ini dapat ditunjukkan dengan kemampuan karyawan dalam mencapai kinerja yang baik dalam perusahaan.

Prihatsanti dan Dewi (2010) mengemukakan bahwa kinerja maksimal merupakan tuntutan organisasi yang ditunjukkan tidak hanya perilaku in-role tetapi juga extra-role yang disebut juga sebagai Organizational Citizenship Behavior $(O C B)$. OCB merupakan suatu perilaku positif individu sebagai anggota organisasi dalam bentuk kesediaan secara sadar dan sukarela untuk bekerja dan memberikan kontribusi pada organisasi lebih daripada apa yang dituntut secara formal dalam organisasi. Kinerja karyawan tentunya didasarkan pada bagaimana kemampuan karyawan dalam menjalankan tugas sesuai dengan job description yang telah ditentukan. Akan tetapi dalam kondisi tertentu, karyawan tidak selalu mampu untuk melaksanakan tugas tersebut disebabkan oleh beberapa hal misalnya karyawan berhalangan karena sebab-sebab tertentu.

Sebuah organisasi bekerja berdasarkan team work. Team work bisa bekerja efektif bilamana terdapat sinergi diantara anggota team work yang terdiri dari pegawai yang baik. Karyawan tidak hanya melakukan tugas pokoknya saja, namun juga mau melakukan tugas-tugas ekstra seperti mau bekerja sama, tolong menolong, memberikan saran sesama karyawan, berpartisipasi aktif, memberikan pelayanan ekstra dan mau menggunakan waktu kerja secara efektif (Lubis, 2015). Tidak terkecuali juga yang berlaku pada karyawan PT. PLN (Persero) Area Palopo dimana setiap karyawan senantiasa dituntut bekerja sama dalam melaksanakan tugasnya. 
Dalam menjalankan job description, karyawan PT. PLN (Persero) Area Palopo terkadang diperhadapkan dengan berbagai hal sehingga tidak mampu menyelesaikan tugasnya secara tuntas. Hal tersebut antara lain terjadi jika karyawan ditunjuk untuk mengikuti DIKLAT di kantor PLN Wilayah Sulselbar dan juga ketika karyawan sedang mengambil cuti kerja. Kondisi tersebut menyebabkan karyawan harus meninggalkan tugas kantor untuk sementara waktu. Pada saat inilah berfungsi yang namanya team work, yang menuntut kesediaan karyawan lainnya untuk berperan ekstra dalam mengambil alih pekerjaan karyawan yang berhalangan agar tugas-tugas dapat terselesaikan sehingga sistem secara keseluruhan tidak terganggu dan dapat berjalan baik.

Organizational Citizenship Behavior (OCB) dipengaruhi oleh beberapa faktor. Vannecia dalam Lubis (2015) menyebutkan bahwa faktor-faktor yang mempengaruhi OCB adalah budaya organisasi, iklim organisasi, kepribadian dan suasana hati (mood), persepsi terhadap dukungan organisasional, dan kualitas interaksi. Selanjutnya Organizational Citizenship Behavior dapat timbul dari berbagai faktor dalam organisasi, diantaranya menurut Robbin (2007) karena adanya komitmen organisasi yang tinggi.

Dalam mencapai kinerja karyawan PT. PLN (Persero) Area Palopo yang baik maka diperlukan perhatian yang serius terhadap faktor-faktor yang mempengaruhinya, yang diantaranya adalah iklim organisasi dan komitmen organisasi. Berdasarkan hal tersebut maka dilakukan penelitian untuk mengetahui pengaruh variabel-variabel tersebut terhadap Organizational Citizenship Behavior $(O C B)$.

\section{KAJIAN LITERATUR DAN PENGEMBANGAN HIPOTESIS}

\section{Iklim Organisasi}

Stringer dalam Wirawan

mendefinisikan bahwa iklim organisasi sebagai koleksi dan pola lingkungan yang menentukan munculnya motivasi serta berfokus pada persepsipersepsi yang masuk akal atau dapat dinilai, sehingga mempunyai pengaruh langsung terhadap kinerja anggota organisasi. Sedangkan Taiguri dan Litwin dalam Wirawan (2007) mengatakan bahwa iklim organisasi merupakan kualitas lingkungan internal organisasi yang secara relatif terus berlangsung, dialami oleh anggota organisasi dan mempengaruhi perilaku mereka serta dapat dilukiskan dalam satu set karakteristik atau sifat organisasi. Kualitas lingkungan organisasi ini dialami oleh para karyawan di dalam organisasinya tersebut dalam bentuk nilai, ciri atau sifat organisasinya. Iklim organisasi dapat didefinisikan sebagai suasana kerja yang diciptakan oleh hubungan antara pribadi dalam organisasi dan merupakan sesuatu yang nyata dirasakan oleh orang-orang yang ada di dalam suatu organisasi.

Iklim organisasi akan menentukan apakah seseorang dapat melaksanakan tugas dan tanggungjawab sesuai prosedur atau tidak (Brahmana \& Sofyandi, 2007). Lebih lanjut Luthans dalam Prihatsanti dan Dewi (2010) menjelaskan bahwa iklim organisasi adalah lingkungan internal organisasi. Iklim organisasi mempengaruhi praktik dan kebijakan SDM yang 
diterima oleh anggota organisasi. Perlu diketahui bahwa setiap organisasi akan memiliki iklim organisasi yang berbeda. Keanekaragaman pekerjaan yang dirancang di dalam organisasi, atau sifat individu yang ada akan menggambarkan perbedaan tersebut. Semua organisasi tentu memiliki strategi dalam memanajemen SDM. Iklim organisasi yang terbuka, bagaimanapun juga hanya tercipta jika semua anggota memiliki persepsi positif pada organisasinya. Iklim organisasi penting untuk diciptakan karena merupakan persepsi seseorang tentang apa yang diberikan oleh organisasi dan dijadikan dasar bagi penentuan tingkah laku anggota selanjutnya.

Greenberg dan Baron dalam Vivid and Rorlen (2007) menyebutkan beberapa dimensi iklim organisasi sebagai berikut:

1) Kepercayaan (dimana setiap karyawan harus berusaha keras dalam mengembangkan dan mempertahankan hubungan yang didalamnya terdapat keyakinan dan kredibilitas yang didukung oleh pernyataan dan tindakan).

2) Pembuatan keputusan bersama/dukungan (para karyawan di semua tingkat dalam organisasi harus diajak komunikasi dan berkonsultasi mengenai semua masalah dalam semua kebijakan organisasi yang relevan dengan kedudukan mereka serta berperan serta dalam pembuatan keputusan dan penetapan tujuan).

3) Kejujuran (suasana umum yang meliputi kejujuran dan keterusterangan harus mewarnai hubungan dalam organisasi, dan karyawan mampu mengatakan apa yang ada dipikiran mereka).
4) Komunikasi (karyawan organisasi relatif tahu akan informasi yang berhubungan dengan tugas mereka).

5) Fleksibilitas/Otonomi (karyawan di setiap tingkat dalam organisasi mempunyai kekuatan pada diri sendiri yang mana dapat menerima saran ataupun menolak dengan pikiran terbuka).

6) Resiko pekerjaan (adanya komitmen dalam organisasi tentang pekerjaan resiko tinggi, kualitas tinggi dan produktivitas tinggi dengan menunjukkan perhatian besar ada anggota lainnya).

H1: diduga terdapat pengaruh positif dan signifikan iklim organisasi terhadap Organizational Citizenship Behavior (OCB).

\section{Komitmen Organisasi}

Menurut Mathis dan Jackson dalam Sopiah (2008) memberikan definisi "Organizational Commitment is the degree to which employees believe in and accept organizational goals and desire to remain with the organization" yaitu komitmen organisasional adalah derajat yang mana karyawan percaya dan menerima tujuantujuan organisasi dan akan tetap tinggal atau tidak akan meninggalkan organisasi.

Berdasarkan beberapa pengertian mengenai komitmen organisasi dari beberapa ahli, mempunyai beberapa kesamaan yang dapat disimpulkan bahwa komitmen organisasi memiliki pengertian sebagai suatu kesetiaan, kepercayaan dan loyalitas yang dimiliki seseorang terhadap organisasi. Jadi komitmen organisasi ini menggambarkan hubungan diantara individu dengan organisasi, jika individu yang memiliki komitmen organisasi yang tinggi, maka ia akan 
mempunyai kesetiaan, kepercayaan dan loyalitas pada organisasi dimana ia bekerja.

Lebih lanjut, Meyer dan Allen dalam Widodo (2010) menjelaskan bahwa terdapat tiga dimensi terpisah komitmen organisasional, yaitu komitmen afektif (affective commitment) keterikatan emosional, identifikasi serta keterlibatan seorang karyawan pada suatu organisasi. Komitmen afektif seseorang akan menjadi lebih kuat bila pengalamannya dalam suatu organisasi konsisten dengan harapan-harapan dan memuaskan kebutuhan dasarnya dan sebaliknya. Komitmen afektif menunjukkan kuatnya keinginan seseorang untuk terus bekerja bagi suatu organisasi karena memang setuju dengan organisasi itu dan memang berkeinginan melakukannya. Karyawan yang mempunyai komitmen afektif yang kuat tetap bekerja dengan organisasi karena menginginkan untuk bekerja pada organisasi itu.

Komitmen berkelanjutan (continuance commitment) merupakan komitmen karyawan yang didasarkan pada pertimbangan apa yang harus dikorbankan bila meninggalkan organisasi atau kerugian yang akan diperoleh karyawan jika tidak melanjutkan pekerjaannya dalam organisasi. Tindakan meninggalkan organisasi menjadi sesuatu yang beresiko tinggi karena karyawan merasa takut akan kehilangan sumbangan yang mereka tanamkan pada organisasi itu dan menyadari bahwa mereka tak mungkin mencari gantinya. Karyawan yang mempunyai komitmen kontinuan yang tinggi akan berada dalam organisasi karena mereka memang membutuhkan untuk bekerja pada organisasi itu.
Komitmen normatif (normative commitment) merupakan komitmen karyawan terhadap organisasinya karena kewajibannya untuk bertahan dalam organisasi untuk alasan-alasan moral atau etis, atau dengan kata lain keyakinan yang dimiliki karyawan tentang tanggung jawabnya terhadap organisasi. Tindakan tersebut merupakan hal benar yang harus dilakukan. Komitmen ini berkaitan dengan perasaan karyawan terhadap keharusan untuk tetap bertahan dalam organisasi. Oleh karena itu, karyawan yang memiliki komitmen normatif yang tinggi akan bertahan dalam organisasi karena merasa wajib atau sudah seharusnya untuk loyal kepada organisasi tersebut.

$\mathrm{H} 2$ : diduga terdapat pengaruh positif dan signifikan komitmen organisasi terhadap Organizational Citizenship Behavior (OCB).

\section{Organizational Citizenship Behavior (OCB)}

Kumar

(2009)

mendefinisikan

Organizational Citizenship Behavior (OCB) sebagai perilaku individu yang memberikan kontribusi pada terciptanya efektifitas organisasi dan tidak berkaitan langsung dengan sistem reward organisasi. Shweta dan Sriarang (2009), menyatakan bahwa OCB ditandai dengan usaha dalam bentuk apapun yang dilakukan berdasarkan kebijaksanaan pegawai yang memberikan manfaat bagi organisasi tanpa mengharapkan imbalan apapun.

Penilaian Kinerja terhadap karyawan biasanya didasarkan pada job description yang telah disusun oleh organisasi tersebut. Dengan demikian, baik-buruknya kinerja seorang karyawan dilihat dari kemampuannya dalam melaksanakan tugas-tugas sesuai dengan pekerjaan yang menjadi tanggung 
jawabnya, sebagaimana tercantum dalam job description. Melakukan pekerjaan sesuai dengan tugas yang ada dalam job description ini disebut sebagai in-role behavior. Sudah seharusnya bila organisasi mengukur kinerja karyawan tidak hanya sebatas tugas-tugas yang terdapat dalam deskripsi kerjanya saja. Bagaimanapun diperlukan peran ekstra demi terselesaikannya tugas-tugas itu. Kontribusi pekerja "di atas dan lebih dari” deskripsi kerja formal inilah yang disebut dengan Organizational Citizenship Behavior (OCB) (Greenberg \& Baron dalam Soegandhi, 2013).

Berdasarkan definisi di atas dapat disimpulkan bahawa Organizational Citizenship Behavior (OCB) merupakan perilaku individu yang ekstra, yang tidak secara langsung atau eksplisit dapat dikenali dalam suatu sistem kerja yang formal, dan mampu meningkatkan efektivitas fungsi organisasi.

H3: diduga terdapat pengaruh positif dan signifikan iklim organisasi dan komitmen organisasi secara bersama-sama terhadap Organizational Citizenship Behavior (OCB).

\section{METODE DAN BAHAN}

Populasi dalam penelitian ini adalah seluruh karyawan PT. PLN (Persero) Area Palopo sebanyak 113 orang yang sekaligus dijadikan sebagai sampel (sampel jenuh). Pengumpulan data primer dilakukan melalui observasi, wawancara dan kuesioner. Observasi digunakan unutk mengamati pola perilaku karyawan PT. PLN (persero) Area Palopo secara langsung di lapangan. Wawancara dengan responden untuk mendapatkan informasi tentang hal-hal yang terkait dengan penelitian ini. Adapun kuesioner yaitu suatu daftar yang berisi pertanyaanpertanyaan yang terkait dengan fakta dan argumen yang dijawab secara tertulis oleh responden.

Adapun teknik analisis data yang digunakan yaitu analisis deskriptif, uji validitas dan reliabilitas, dan analisis regresi linear berganda. Analisis deskriptif berisi tentang bahasan secara deskritif mengenai tanggapan yang diberikan responden pada kuesioner. Statistik deskritif adalah statistik yang digunakan untuk menganalisa data dengan cara mendeskripsikan atau mengambarkan data yang telah terkumpul sebagaimana adanya tanpa bermaksud membuat kesimpulan yang berlaku untuk umum atau generalisasi.

Pengujian validitas item-item pertanyaan dalam kuesioner bertujuan untuk mengetahui apakah item-item tersebut benar-benar mengukur konsep-konsep yang dimaksudkan dalam penelitian ini dengan tepat. Suatu kuisioner dikatakan valid jika mampu mengungkapkan sesuatu yang diukur oleh kuisioner tersebut. Jika koefisien korelasi sama dengan 0,3 atau lebih (paling kecil 0,3) maka butir instrumen dinyatakan valid, dan tidak valid apabila koefisien korelasi lebih kecil dari 0,3.

Uji reliabilitas ini merupakan bentuk uji kualitas data yang menunjukkan stabilitas dan konsistensi dari instrumen untuk mengukur konstruk/variabel. Nilai batas yang diperkenankan untuk menilai atau menguji apakah setiap variabel dapat dipercaya, handal dan akurat dipergunakan formula Alpha Cronbach. Suatu kuisioner dikatakan reliabel atau handal jika jawaban responden atas pernyataan adalah konsisten atau stabil dari waktu ke waktu. Instrumen dinyatakan reliabel apabila nilai alpha cronbanch $\geq 0,60$, jika 
cronbanch alpha $<0,60$ maka dikatakan tidak reliabel.

Regresi linear berganda merupakan teknik analisis regresi yang digunakan untuk menjelaskan hubungan antara variabeldependen dengan variabel independen dan bertujuan untuk memperkirakan/meramalkan nilai $\mathrm{Y}$ dan untuk mengetahui besarnya pengaruh setiap variabel bebas yang terdapat dalam persamaan. Adapun rumus persamaan regresi berganda dari penelitian ini sebagai berikut:

$Y=a+b_{1} X_{1}+b_{2} X_{2}+e$

Dimana:

$$
\begin{array}{ll}
\mathrm{Y} & =\text { Organizational Citizenship } \\
& \text { Behavior }(O C B) \\
\mathrm{A} & =\text { Konstanta (intercept) } \\
\mathrm{X} 1 & =\text { Iklim Organisasi } \\
\mathrm{X} 2 & =\text { Komitmen Organisasi } \\
\mathrm{b} 1 \text { dan b2 = } & \text { Koefisien Regresi } \\
\mathrm{e} & =
\end{array}
$$

Untuk mendapatkan hasil dari metode perhitungan analisis ini maka digunakan bantuan dalam pengolahan data dengan menggunakan program SPSS versi 21.

\section{HASIL DAN PEMBAHASAN}

\section{Analisis Deskriptif}

Setelah kuesioner disebarkan kepada seluruh sampel penelitian, pada kenyataannya kuesioner yang dikembalikan sebanyak 105 kuesioner atau sekitar $92,92 \%$, sedangkan yang tidak dikembalikan sebanyak 8 kuesioner atau 7,08\%. Deskripsi resonden yang digunakan dalam penelitian ini bertujuan untuk mengetahui jumlah responden berdasarkan beberapa kriteria, antara lain berdasarkan jenis kelamin, usia, pendidikan dan masa kerja.

Tabel 1. Deskripsi Responden berdasarkan Jenis Kelamin

\begin{tabular}{|c|c|c|}
\hline Jenis Kelamin & Frekuensi & Persentase (\%) \\
\hline Laki-laki & 95 & 90,48 \\
\hline Perempuan & 10 & 9,52 \\
\hline Jumlah & 105 & 100 \\
\hline
\end{tabular}

Jumlah responden yang paling banyak berdasarkan jenis kelamin adalah laki-laki yaitu sebanyak 95 orang dengan persentase $90,48 \%$ dibanding dengan perempuan yang hanya sebanyak 10 orang dengan persentase $9,52 \%$. Hal ini sesuai dengan kondisi pada perusahaan dimana beberapa unit pekerjaan pada PT. PLN (Persero) Area Palopo yang sedianya memang diperuntukkan bagi karyawan laki-laki, misalnya pada operator distribusi, engineer dan technician.

Tabel 2. Deskripsi Responden berdasarkan Usia

\begin{tabular}{|c|c|c|}
\hline Usia & Frekuensi & Persentase $(\%)$ \\
\hline$<30$ tahun & 27 & 25,71 \\
\hline $30-35$ tahun & 6 & 5,71 \\
\hline $36-40$ tahun & 2 & 1,91 \\
\hline $41-45$ tahun & 9 & 8,57 \\
\hline $46-50$ tahun & 19 & 18,1 \\
\hline$>50$ tahun & 42 & 40 \\
\hline Jumlah & 105 & 100 \\
\hline
\end{tabular}

Sedangkan berdasarkan usia, responden penelitian paling banyak yang berusia $>50$ tahun yaitu sebanyak 42 orang dengan persentase $40 \%$, sedangkan yang paling sedikit berusia antara 36-40 tahun yaitu hanya sebanyak 2 orang dengan persentase $1,91 \%$. 
Tabel 3. Deskripsi Responden berdasarkan Pendidikan

\begin{tabular}{|c|c|c|}
\hline Pendidikan & Frekuensi & Persentase (\%) \\
\hline SMA & 56 & 53,33 \\
\hline D1 - D3 & 20 & 19,05 \\
\hline S1 & 28 & 26,67 \\
\hline S2 & 1 & 0,95 \\
\hline S3 & 0 & 0 \\
\hline Jumlah & 105 & 100 \\
\hline
\end{tabular}

Dari sisi pendidikan, responden yang paling banyak mempunyai pendidikan SMA yaitu sebanyak 56 orang dengan persentase 53,33\%, sedangkan yang paling sedikit adalah responden dengan pendidikan S2 yaitu sebanyak 1 orang dengan persentase $0,95 \%$.

Tabel 4. Deskripsi Responden berdasarkan Masa Kerja

\begin{tabular}{|c|c|c|}
\hline Masa Kerja & Frekuensi & Persentase $(\%)$ \\
\hline $1-5$ tahun & 23 & 21,9 \\
\hline $6-10$ tahun & 10 & 9,52 \\
\hline $11-20$ tahun & 17 & 16,19 \\
\hline $21-30$ tahun & 40 & 38,1 \\
\hline $31-40$ tahun & 15 & 14,29 \\
\hline Jumlah & 105 & 100 \\
\hline
\end{tabular}

Berdasarkan masa kerja, jumlah responden yang paling banyak memiliki masa kerja 21-30 tahun yaitu sebanyak 40 orang dengan persentase $38,1 \%$, sedangkan responden dengan masa kerja 610 tahun adalah yang paling sedikit yaitu sebanyak 10 orang dengan persentase $9,52 \%$.

\section{Uji Validitas dan Reliabilitas}

Dari hasil pengujian validitas, didapatkan bahwa semua item pernyataan yang digunakan dalam penelitian ini adalah valid. Hal tersebut dapat dilihat dari nilai masing-masing item pernyataan yang memiliki Corrected item-total correlation yang lebih besar dari 0,30. Sedangkan untuk pengujian reliabilitas didapatkan hasil bahwa variabel-variabel penelitian telah reliabel karena keseluruhan variabel memiliki nilai cronbach's alpha yang lebih besar dari 0,60 sehingga layak digunakan untuk menjadi alat ukur instrumen kuesioner dalam penelitian ini.

Tabel 5. Uji Validitas

\begin{tabular}{|c|c|c|c|c|}
\hline No & Variabel & $\begin{array}{c}\text { Item } \\
\text { Pernyataan }\end{array}$ & $\begin{array}{c}\text { Corrected } \\
\text { item-total } \\
\text { correlation }\end{array}$ & Keterangan \\
\hline \multirow{6}{*}{1} & \multirow{6}{*}{$\begin{array}{l}\text { Iklim } \\
\text { Organisa } \\
\text { si }\end{array}$} & 1 & 0.571 & Valid \\
\hline & & 2 & 0.522 & Valid \\
\hline & & 3 & 0.624 & Valid \\
\hline & & 4 & 0.507 & Valid \\
\hline & & 5 & 0.617 & Valid \\
\hline & & 6 & 0.447 & Valid \\
\hline \multirow{6}{*}{2} & \multirow{6}{*}{$\begin{array}{l}\text { Komitm } \\
\text { en } \\
\text { Organisa } \\
\text { si }\end{array}$} & 7 & 0.498 & Valid \\
\hline & & 8 & 0.473 & Valid \\
\hline & & 9 & 0.488 & Valid \\
\hline & & 10 & 0.334 & Valid \\
\hline & & 11 & 0.544 & Valid \\
\hline & & 12 & 0.418 & Valid \\
\hline \multirow{8}{*}{3} & \multirow{8}{*}{ OCB } & 13 & 0.571 & Valid \\
\hline & & 14 & 0.595 & Valid \\
\hline & & 15 & 0.6 & Valid \\
\hline & & 16 & 0.484 & Valid \\
\hline & & 17 & 0.47 & Valid \\
\hline & & 18 & 0.402 & Valid \\
\hline & & 19 & 0.496 & Valid \\
\hline & & 20 & 0.621 & Valid \\
\hline
\end{tabular}

Tabel 6. Uji Reliabilitas

\begin{tabular}{|l|c|c|}
\hline \multicolumn{1}{|c|}{ Variabel } & $\begin{array}{c}\text { Alpha } \\
\text { Cronbach }\end{array}$ & Keterangan \\
\hline Iklim Organisasi & 0.754 & Reliabel \\
\hline Komitmen Organisasi & 0.763 & Reliabel \\
\hline OCB & 0.759 & Reliabel \\
\hline
\end{tabular}




\section{Analisis Regresi Linear Berganda}

Tabel 7. Hasil Perhitungan Regresi

\section{Coefficients $^{\mathrm{a}}$}

\begin{tabular}{|c|c|c|c|c|c|}
\hline \multirow[t]{2}{*}{ Model } & \multicolumn{2}{|c|}{$\begin{array}{c}\text { Unstandardized } \\
\text { Coefficients }\end{array}$} & \multirow{2}{*}{\begin{tabular}{|c|}
$\begin{array}{c}\text { Standard } \\
\text { ized } \\
\text { Coeffici } \\
\text { ents }\end{array}$ \\
Beta \\
\end{tabular}} & \multirow[t]{2}{*}{$\overline{\mathrm{t}}$} & \multirow[t]{2}{*}{ Sig. } \\
\hline & B & $\begin{array}{l}\text { Std. } \\
\text { Error }\end{array}$ & & & \\
\hline$($ Constant $)$ & 4.290 & 2.309 & & 1.858 & .066 \\
\hline $1 \begin{array}{ll}\text { Iklim } & \text { Organisasi }\end{array}$ & .612 & .109 & .458 & 5.601 & .000 \\
\hline $\begin{array}{l}\text { Komitmen } \\
\text { Organisasi }\end{array}$ & .508 & .117 & .355 & 4.345 & .000 \\
\hline
\end{tabular}

a. Dependent Variable: Organizational Citizenship Behavior (OCB)

Berdasarkan hasil di atas, maka diperoleh persamaan regresi sebagai berikut:

$$
Y=4,290+0,612 X 1+0,508 \times 2
$$

Persamaan tersebut mengandung arti bahwa konstanta bernilai positif sebesar 4,290 menunjukkan bahwa jika iklim organisasi dan komitmen organisasi bernilai tetap maka Organizational Citizenship Behavior (OCB) meningkat sebesar 4,290. Koefisien regresi dari variabel X1 sebesar 0,612 menunjukkan adanya arah pengaruh positif iklim organisasi terhadap Organizational Citizenship Behavior (OCB) pada karyawan PT. PLN (Persero) Area Palopo. Apabila iklim organisasi mengalami peningkatan sebesar satu satuan, maka Organizational Citizenship Behavior (OCB) akan mengalami peningkatan sebesar 0,612; dengan asumsi komitmen organisasi dalam keadaan tetap (konstan). Koefisien regresi dari variabel X2 sebesar 0,508 menunjukkan adanya arah pengaruh positif komitmen organisasi terhadap Organizational Citizenship Behavior $(O C B)$ pada karyawan PT. PLN (Persero) Area
Palopo. Apabila komitmen organisasi mengalami peningkatan sebesar satu satuan, maka Organizational Citizenship Behavior (OCB) akan mengalami peningkatan sebesar 0,508; dengan asumsi iklim organisasi dalam keadaan tetap (konstan).

Berikutnya, hasil uji $\mathrm{T}$ antara pengaruh iklim organisasi terhadap Organizational Citizenship Behavior (OCB) sebesar 5,601 yang lebih besar dari $\mathrm{T}_{\text {tabel }}(1,658)$ dengan nilai signifikan 0,000 yang lebih kecil dari 0,05. Hasil ini menunjukkan bahwa iklim organisasi berpengaruh positif signifikan terhadap Organizational Citizenship Behavior (OCB). Hasil uji $\mathrm{T}$ antara pengaruh komitmen organisasi terhadap Organizational Citizenship Behavior (OCB) sebesar 4,345 yang lebih besar dari $\mathrm{T}_{\text {tabel }}$ $(1,658)$ dengan nilai signifikan 0,000 yang lebih kecil dari 0,05. Hasil ini menunjukkan bahwa komitmen organisasi berpengaruh positif signifikan terhadap Organizational Citizenship Behavior (OCB).

Tabel 8. Uji F (simultan)

ANOVA $^{\mathrm{a}}$

\begin{tabular}{|c|r|r|r|r|r|}
\hline Model & $\begin{array}{c}\text { Sum of } \\
\text { Squares }\end{array}$ & df & $\begin{array}{c}\text { Mean } \\
\text { Square }\end{array}$ & F & Sig. \\
\hline $\begin{array}{l}\text { Regres } \\
\text { sion }\end{array}$ & 831.698 & 2 & 415.849 & 63.948 & $.000^{\circ}$ \\
$1 \quad \begin{array}{l}\text { Residu } \\
\text { al } \\
\text { Total }\end{array}$ & 721.820 & 111 & 6.503 & & \\
\hline
\end{tabular}

a. Dependent Variable: Organizational Citizenship Behavior (OCB)

b. Predictors: (Constant), Komitmen Organisasi, Iklim Organisasi 
Selanjutnya, nilai $\mathrm{F}$ hitung didapatkan sebesar 63,948 yang lebih besar dari $\mathrm{F}_{\text {tabel }}(3,08)$ dengan nilai signifikansi 0,000 yang lebih kecil dari 0,05. Hal ini menunjukkan bahwa iklim organisasi dan komitmen organisasi secara bersama-sama berpengaruh positif signifikan terhadap Organizational Citizenship Behavior $(O C B)$.

Pada kenyataannya bahwa iklim organisasi mempunyai pengaruh positif dan signifikan terhadap Organizational Citizenship Behavior $(O C B)$ karyawan PT. PLN (Persero) Area Palopo. Hal ini mengandung pengertian bahwa Organizational Citizenship Behavior (OCB) karyawan akan mengalami peningkatan ketika terjadi peningkatan iklim organisasi, antara lain meliputi perasaan senang karyawan dalam menyelesaikan tugas atau pekerjaannya, karyawan diberikan kesempatan berpendapat, karyawan sangat bertanggung jawab dalam tugas dan pekerjaannya.

Sejalan dengan pembahasan di atas bahwa komitmen organisasi pada kenyataannya mempunyai pengaruh positif dan signifikan terhadap Organizational Citizenship Behavior $(O C B)$ karyawan PT. PLN (Persero) Area Palopo. Hal ini mengandung pengertian bahwa Organizational Citizenship Behavior (OCB) karyawan akan mengalami peningkatan ketika terjadi peningkatan komitmen organisasi karyawan, antara lain melalui adanya keterikatan emosional tinggi antara karyawan terhadap perusahaan, karyawan merasa bangga menjadi bagian dari perusahaan, dan karyawan berkewajiban moral untuk setia pada perusahaan.
Pada kenyataannya bahwa iklim organisasi dan komitmen organisasi secara bersama-sama mempunyai pengaruh positif dan signifikan terhadap Organizational Citizenship Behavior $(O C B)$ karyawan PT. PLN (Persero) Area Palopo. Hal ini mengandung pengertian bahwa Organizational Citizenship Behavior (OCB) karyawan akan mengalami peningkatan ketika terjadi peningkatan iklim organisasi dan komitmen organisasi karyawan, antara lain melalui perasaan senang karyawan dalam menyelesaikan tugas atau pekerjaannya, karyawan diberikan kesempatan berpendapat, bertanggung jawab dalam tugas, adanya keterikatan emosional tinggi antara karyawan terhadap perusahaan, karyawan merasa bangga menjadi bagian dari perusahaan, dan karyawan berkewajiban moral untuk setia pada perusahaan.. Begitu pun sebaliknya, bahwa tanpa iklim organisasi dan komitmen organisasi yang terbangun dalam diri karyawan maka Organizational Citizenship Behavior (OCB) akan mengalami penurunan, adapun penyebabnya dapat disebabkan karena karyawan dalam menyelesaikan pekerjaannya tidak merasa senang, karyawan tidak diberikan kesempatan mengeluarkan pendapat, tidak bertanggung jawab dalam tugas, tidak adanya keterikatan emosional terhadap perusahaan, menganggap bukan bagian dari perusahaan, dan tidak ada kewajiban moral untuk setia kepada perusahaan.

\section{SIMPULAN}

Adapun kesimpulan dari penelitian ini bahwa iklim organisasi dan komitmen organisasi berpengaruh positif dan signifikan terhadap Organizational Citizenship Behavior (OCB) pada 
karyawan PT. PLN (Persero) Area Palopo baik secara parsial maupun secara simultan. Dalam rangka meningkatkan Organizational Citizenship Behavior (OCB) pada karyawan PT. PLN (Persero) Area Palopo, maka pihak pimpinan atau manajer perlu memperhatikan iklim organisasi karyawan (seperti; perasaan senang karyawan dalam menyelesaikan tugas atau pekerjaannya, karyawan diberikan kesempatan berpendapat, bertanggung jawab dalam tugas) maupun komitmen organisasi (seperti; membangun keterikatan emosional yang tinggi antara karyawan terhadap perusahaan, perasaan bangga karyawan karena menjadi bagian dari perusahaan, dan berkewajiban moral karyawan untuk setia pada perusahaan).

\section{DAFTAR PUSTAKA}

Andriani, Gita et al. 2012. Organizational Citizenship Behavior dan Kepuasan Kerja pada Karyawan. Jurnal Penelitian Psikologi, 3(1): 341-354.

Brahmana, S.S. dan Sofyandi, H. 2007. Transformational Leadership dan Organization Citizenship Behavior di Utama. Laporan Penelitian. Tidak diterbitkan.

Kumar, K., et al. 2009. Linking the Big Five Personality Domains to Organizational Citizenship Behavior. International Journal of Psychological Studies, 1(2):73-81.

Lubis, M. Saleh. 2015. Pengaruh Iklim Organisasi dan Komitmen Organisasi terhadap Pembentukan Organizational Citizenship Behavior (OCB) Karyawan dalam rangka Peningkatan Kinerja. E-Jurnal Apresiasi Ekonomi 3(2): 75-84.

Prihatsanti, Unika dan Dewi, Kartika Sari. 2010. Hubungan antara Iklim Organisasi dan Organizational Citizenship Behavior (OCB) pada Guru SD Negeri di Kecamatan
Mojolaban Sukoharjo. Jurnal Psikologi Undip 7(1):11-17.

Robbins, Stephen P. 2007. Perilaku Organisasi. Edisi kesepuluh. Jakarta: Indeks Kelompok Gramedia.

Shweta, J., and Srirang, J. 2009. Determinants of Organizational Citizenship Behavior: A Review of Literature. Journal of Management and Public Policy, 1(2): 27-36.

Soegandhi, Vannecia Marchelle, et al. 2013. Pengaruh Kepuasan Kerja dan Loyalitas Kerja terhadap Organizational Citizenship Behavior pada Karyawan PT, Surya Timur Sakti Jatim. Jurnal Agora 1(1): 1-12

Sopiah. 2008. Perilaku Organisasional. Yogyakarta: Penerbit Andi.

Sugiyono. 2008. Metode Penelitian Bisnis. Bandung: Alfabeta.

Vivi dan Rorlen. 2007. Pengaruh Iklim Organisasi dan Kedewasaan terhadap Kinerja Karyawan pada PT Graha Tungki Arsitektika Jakarta. Business \& Manajement Journal Bunda Mulia, 3(1):5159.

Waspodo, Agung AWS dan Minadaniati, Lussy. 2012. Pengaruh Kepuasan Kerja dan Iklim Organisasi terhadap Organizational Citizenship Behavior (OCB) karyawan pada PT. Trubus Swadaya Depok. Jurnal Riset Manajemen Sains Indonesia (JRMSI), 3(1): $1-16$.

Wirawan, 2007. Budaya dan Iklim Organisasi: Teori, Aplikasi, dan Penelitian. Jakarta: Salemba Empat. 